Sympozjum

Rok XXIV 2020, nr 1(38), s. 51-64

\title{
ks. Jan Krzysztof Miczyński
}

Katolicki Uniwersytet Lubelski Jana Pawła II w Lublinie ORCID: 0000-0003-1052-5655; e-mail: jan.miczynski@kul.pl https://doi.org/10.4467/25443283SYM.20.003.12120

\section{SERCE JEZUSA \\ - MISTERIUM MIŁOŚCI UOSOBIONEJ \\ SACRED HEART \\ - THE MYSTERY OF PERSONIFIED LOVE}

\begin{abstract}
Abstrakt
Kult Serca Jezusowego jest oddawaniem czci całej Osobie Wcielonego Bożego Syna. Jezus Chrystus jest uosobioną Miłością, jest Kimś, kto jest tylko miłością. Więź miłości łącząca serce człowieka i Serce Jezusa prowadzi ku spełnieniu osobowemu. Wprowadza w niezwykłą przestrzeń miłości międzyosobowej, w odkupioną społeczność, która tworzy Mistyczne Ciało Chrystusa, ożywiane jednym sercem (por. Dz 4,32), ku chwale majestatu Boga (por. Ef 1,12.14), w Komunii Osób Niestworzonych. Serce Jezusa jest zwierciadłem ukazującym blask miłości Boga, godność i wielkość powołania osób stworzonych na wzór obrazu Bożego Syna (por. Rz 8,29), jak również doniosłość nowego świata (por. Ap 21,5), rozpoczynającego się już tu, na ziemi.

Słowa kluczowe: Serce Jezusa, serce, osoba, kult, miłość, rozwój, społeczność, wspólnota
\end{abstract}




\section{Abstract}

The cult of the Sacred Heart of Jesus is glorification of the Incarnated Person of the Son of God. Jesus Christ is a personification of Love, He is someone, who is exclusively love. The bond of love between Sacred Heart and a human's heart leads to personal fulfilment. It introduces one into extraordinary space of interpersonal love, also in redeemed community, which creates the Mystical Body of Christ, which is animated by one heart (cf. Acts 4,32), to glorify God's Majesty (cf. Eph 1,12.14), in Communion of Uncreated Persons. Sacred Heart of Jesus is the mirror which reflects the dazzle of God's love, dignity and magnitude of vocation of people created as an image of God's Son (cf. Rom 8,29), and also significance of a new world (cf. Rev 21,5), which has begun here, on earth.

Keywords: Sacred Heart, heart, person, cult, love, progress, community

Ludzkie serce (hebr. leb, lebab, gr. kardia) jest nie tylko szlachetnym organem w organizmie ludzkim, ale również symbolem najgłębszego miejsca w człowieku; mieszkania, w którym on przebywa, gdzie według języka biblijnego - „zstępuje”. Jest ono centrum osoby ludzkiej, w którym realizuje się realne i osobowe ,ja" ontyczne, głębsze od samoświadomości, wymykające się zwykłym, ludzkim, rozumowym zdolnościom poznawczym. I dlatego człowiek nie potrafi do końca poznać samego siebie i innych (por. Jdt 8,14 ), a jego serce pozostaje tajemnicą, dostępną ostatecznie jedynie Bogu (por. 1 Krl 8,39; 2 Krn 6,30; Ps 7,10; Łk 16,15; Dz 1,24; Rz 8,27; 1 Tes 2,4). Serce jest miejscem poznawania prawdy, rozumienia jej (por. Pwt 30,1; Joz 23,14) i zajmowania wobec niej stanowiska (por. Pwt 18,21), podejmowania decyzji (por. Pwt 4,31), planowania (por. 2 Sm 7,3; Prz 19,21), działania, opowiadania się za dobrem moralnym albo za złem, wybierania życia bądź śmierci, miłości bądź nienawiści. Jest ośrodkiem upominania (por. Ps 16,7) i nakazu kroczenia za dobrem (por. 2 Kor 9,7). Jest miejscem zawierania oraz pogłębiania przymierza z Bogiem ${ }^{1}$ - i stawania się w pełni osobą. Czasem też -

\footnotetext{
${ }^{1}$ Por. Katechizm Kościoła katolickiego, Poznań 1994, 2563.
} 
niestety - staje się tragicznym miejscem grzechu, unoszenia się pychą (por. Pwt 8,14) oraz złorzeczenia (por. Hi 1,5); a tym samym osłabienia albo wręcz zerwania osobowej więzi z Bogiem (por. 1 Krl 11,9), dramatycznej negacji samego siebie i karłowacenia aż do rozmiarów anty-osoby.

Biblia uczy, że ludzkie serce jest miejscem uczuciowego przeżywania wielorakich wydarzeń (por. 2 Sm 13,20). W nim pojawiają się trudne emocje: strachu (por. Wj 26,36; Pwt 20,3; Joz 5,1), boleści (por. Pwt 15,10), wzgardy (por. 1 Krn 15,29), smutku (por. 1 Sm 1,8), troski (por. 1 Mch 6,10; 9,7), oburzenia (por. 1 Mch 10,74), wzburzenia (por. Hi 15,12), złości (por. Ps 41,7), zazdrości (por. Prz 23,17), przerażenia (por. Hi 33,16), przygnębienia (por. Koh 11,10), zwątpienia (por. 1 Mch 12,28), zniechęcenia (por. Syr 2,13). Napełnia się ono również uczuciami pozytywnymi: radością (por. Sdz 18,20), wdzięcznością (por. 1 Krl 10,24), męstwem (por. Ps 31,25), ufnością (por. Ps 84,6). Z serca człowieka pochodzą myśli (por. Mt 15,19; Mk 7,21) i słowa (por. Łk 6,45); jest ono jego zwierciadłem (por. Prz 27,19). Sumując, serce - będące ośrodkiem życiowej siły, myślenia, woli, uczuć - określa całą wewnętrzną naturę osoby².

Kult Serca Jezusowego jest oddawaniem czci i wyrazem szacunku wobec całej Osoby Wcielonego Bożego Syna, i ukazuje, że Jezus Chrystus jest uosobioną Miłością, jest Kimś, kto jest tylko miłością ${ }^{3}$. Przed oczami wierzących jawi się niezwykłe misterium: oto Osoba Syna Bożego, zrodzona przed wiekami z Ojca Przedwiecznego, mocą Ducha Świętego i za zgodą Maryi stała się w pełni czasów (por. Ga 4,4) również osobą ludzką, z całą jej wewnętrzną złożonością. Bóg, który jest miłością (por. $1 \mathrm{~J} 4,8$ ), przyjął ludzkie serce, a to znaczy, że stało się ono nie tylko miejscem epifanii Boga, ale wręcz żywym Sercem Syna Bożego. Rozważanie niezwykłego misterium Serca Jezusa:

2 Por. A. Kiejza, Serce, w: E. Gigilewicz (red.), Encyklopedia katolicka, t. 18, Lublin 2013, k. 6-7.

3 Por. C. S. BARTnik, Serce Jezusa, w: tenże, Światło świata. Homilie, kazania, przemówienia, Lublin 1991, s. 179. Być może słowo „serce” rozumie się współcześnie - pod wpływem epoki romantyzmu - trochę redukcjonistycznie, tzn. jedynie jako świat wewnętrznych przeżyć osoby: jej doznań, uczuć, najgłębszych tajemnic. 
- odsłania prawdę tajemnicy wcielenia ${ }^{4}$ - o głębi przeżywania przez Chrystusa swojej ziemskiej egzystencji na sposób Miłości i włączeniu - w nowy sposób (poprzez odkupienie) - świata ludzkiego w świat Trójcy Świętej;

- nakreśla perspektywę uzdrowienia ludzkiego serca i spełnienia osobowego w miłosnym zjednoczeniu z Sercem Zbawiciela;

- wprowadza w niezwykłą przestrzeń miłości międzyosobowej, w odkupioną społeczność, która tworzy Mistyczne Ciało Chrystusa, ożywiane jednym sercem (por. Dz 4,32), ku chwale majestatu Boga (por. Ef 1,12.14), w Komunii Osób Niestworzonych.

Serce Jezusa jest zwierciadłem ukazującym blask miłości i piękna Osób Niestworzonych, godność i wielkość powołania osób stworzonych (na obraz Boży, por. Rdz 1,27; na wzór obrazu Bożego Syna, por. Rz 8,29), jak również doniosłość nowego świata (por. Ap 21,5), rozpoczynającego się już tu, na ziemi.

\section{Serce Jezusa - Miłość zrodzona z Ojca Przedwiecznego i z Maryi}

Tekst Litanii do Najświętszego Serca Pana Jezusa przypomina prawdę, że Serce Jezusa jest sercem Syna Ojca Przedwiecznego. Tym samym wskazuje na źródło - jest nim Bóg Ojciec, który przed wiekami zrodził z miłości Osobę Syna. Jednocześnie ten sam tekst - w kolejnym wezwaniu - mówi, że to Serce zostało mocą Ducha Świętego utworzone w łonie Matki Dziewicy. Czy nie kryje się tu jakiś paradoks? Istniejące odwiecznie Serce zostało utworzone w miejscu i w czasie... Czy mogło Ono zostać dwukrotnie zrodzone - najpierw z Boga, a później z człowieka? Otóż tekst litanii podkreśla, że Serce Jezusa jest istotowo zjednoczone ze Słowem Bożym. Jest zatem jednym, tym samym - utkane i zrodzone wcześniej z miłości Ojca, a w czasie zrodzone z ziemskiej Matki ${ }^{5}$. Na gruncie

4 Przypominał o tym w swoim nauczaniu św. Jan Paweł II. Zob. J. Misıurek, Źródło życia i świętości. Polska teologia kultu Najświętszego Serca Jezusa, Lublin 2014, s. 211.

5 Por. C. S. BARTnik, Serce Jezusa, dz. cyt., s. 179. 
personalizmu chrześcijańskiego powiedzielibyśmy, że za pośrednictwem Maryi „ludzka osoba zosta[ła] «wrodzona» w Osobę Słowa przez Ducha Świętego (...). Stąd jest to Najwyższe Dzieło Ducha Świętego ze wszystkich”6. Jezus Chrystus jest pełną osobą ludzką i pełną Osobą Bożą

Obserwując życie ludzkie, można dostrzec pewne lustrzane odbicie wydarzenia wcielenia (lustrzane, a zatem nie takie same): najpierw osoba ludzka tworzy się - przy współdziałaniu stwórczym Boga - w łonie matki, potem rodzi się w określonym miejscu i czasie, a następnie - według słów Chrystusa - powinna narodzić się z Boga (por. J 1,13; 3,3-5), dla życia wiecznego (por. J 3,15). W życiu każdego człowieka winny nastąpić podwójne narodziny. Oczywiście, człowiek, rodząc się „powtórnie” z Miłości Osób Bożych, pozostaje tym samym człowiekiem, odrębnym od innych, ale jest jednocześnie w Chrystusie „nowym stworzeniem” (2 Kor 5,17).

Wydaje się, że można powiedzieć, iż Jezus, jako człowiek, otrzymał wiele cech osobowości od swojej Matki. Jego Serce - w wymiarze ludzkim - miało coś z kolorytu serca Maryi. Cała była oddana Bogu, stała się bowiem Jego „nosicielką" - nie tylko somatyczną, ale i duchową; otwarta na Jego słowo, natchnienia, działanie. Jej duchowość wyrażała się w postawie zawierzenia Stwórcy do końca, w posłuszeństwie, ufności i miłości. Ta miłość miała zaś u niej kształt dziewiczy i zarazem macierzyński: wobec swego Syna, a także stopniowo - w sposób duchowy - wobec całego stworzenia. Cała była dla innych, w postawie służby, oddając wszystko bez zostawiania czegokolwiek dla siebie, ofiarowując największy Dar - swojego Syna - na odkupienie całego świata ${ }^{8}$. Przyjmując taką postawę duchową, pozwoliła, by wypełniło się w jej życiu słowo prorockie wypowiedziane przez Symeona, gdy przyniosła Dziecię Jezus do świątyni, mó-

${ }_{6}^{6}$ Tenże, Dogmatyka katolicka, t. 1, Lublin $1999^{1}$, s. 589.

${ }^{7}$ Nie ma tu mowy o błędzie nestorianizmu, bo w Chrystusie nie ma dwóch osób. Wcielenie jest unikalnym i niepowtarzalnym wydarzeniem, w którym Osoba Słowa Bożego spełnia samą sobą człowieczeństwo (wraz ze współcześnie rozumianą „osobą”) Jezusa. Jest to misteryjny, niezwykły przypadek relacji osobotwórczej - zasymilowania osoby ludzkiej przez Osobę Bożą. Chrystus jest Kimś Jednym i Tym samym - w wymiarze ontycznym, podmiotowym, jaźniowym, historycznym. Por. tamże, s. 590. Por. także: TENżE, „Ja” Chrystusa, w: tenże, Chrystus - Syn Boga Żywego, Lublin 2000, s. 251-252.

${ }^{8}$ Por. Tenże, Matka Boża, Lublin 2012, s. 118-120. 
wiącego o tym, że jej „duszę miecz przeniknie, by na jaw wyszły zamysły serc wielu” (Łk 2,35). Przeszyte bólem serce Maryi, trwające przy otwieranym włócznią Sercu ukrzyżowanego Syna, objęło miłością matczyną serca wszystkich wierzących (por. J 19,26: „Niewiasto, oto syn Twój”).

Duch Święty - będący węzłem miłości między Ojcem i Synem - sprawia, że w tajemnicy wcielenia miłość Syna do Ojca przyobleka się w szatę ludzką. Świat wewnętrznych przeżyć, duchowego życia Jezusa z Nazaretu, Jego myśli, decyzje, słowa i czyny objawiają tajemnicę Serca Ojca. Serce Jezusa jest czystą Miłością - odblaskiem Jego Miłości. W Sercu Jezusa - jak mówi treść wspomnianej litanii - „Ojciec bardzo sobie upodobał”. Można tu dostrzec pewne nawiązanie do fragmentu Ewangelii św. Mateusza, gdzie zacytowane jest słowo proroka Izajasza, odniesione do Jezusa: „Oto mój Sługa, którego wybrałem; Umiłowany mój, w którym moje serce ma upodobanie" (12,18; por Iz 42,1-4). Serce Ojca zjednoczone z Sercem Syna, o czym świadczą słowa Chrystusa: „Ja i Ojciec jedno jesteśmy” (J 10,30), jak również: „Kto Mnie widzi, widzi także i Ojca” (J 14,9).

Symbolem złączenia w Sercu Jezusa życia doczesnego z wiecznym jest krew i woda, które wypłynęły na Krzyżu Świętym, gdy zostało Ono przebite. Krew w Biblii oznacza ziemską egzystencję, naznaczoną cierpieniem, ludzką śmiercią, a także symbolizuje przymierze z Bogiem (Por. Wj 24,8; Hbr 9,1-7; Łk 22,20). Woda zaś oznacza Bożę łaskę, „wodę żywą” (J 7,37-38), „wodę życia” (Ap 21,6) ${ }^{9}$. Strumień krwi i wody płynący z najgłębszego misterium Osoby Chrystusa, z Ofiary Najświętszej, to strumień Miłości rozlewającej się na cały świat, dający ludziom możliwość nowego, nieskończonego życia. Woda ta, którą człowiek otrzymuje od Chrystusa, gasi jego pragnienie i „stanie się w nim źródłem tryskającym ku życiu wiecznemu” $(\mathrm{J} 4,14)$. Karmienie się Chrystusem Eucharystycznym, spożywanie godnie Jego Ciała i Krwi, jest początkiem tego życia i oczekiwaniem na powstanie z martwych - według zapowiedzi Pana Jezusa (por. J 6,54 $)^{10}$. Serce Jezusa - Miłość zrodzona z Ojca Przedwiecznego i Maryi

9 Por. Tenże, Serce Jezusa, dz. cyt., s. 179.

10 Por. P. Łabuda, Eucharystia darem miłości Serca Chrystusowego. „Bierzcie i jedzcie, to jest Ciało moje" (Mt 26,26 par.), w: A. Gąsior, J. Królikowski, P. Łabuda (red.), Tajemnica Najświętszego Serca Jezusa. Sympozjum z okazji 50-lecia ogłoszenia przez Piusa XII encykliki Haurietis aquas, Wadowice, 17-19 listopada 2006 r., Tarnów 2007, s. 66-84. 
- zostaje otwarte i zaprasza, by wniknąć w Jego głębię oraz mocą Ducha Świętego otrzymać nowe życie, wracając jako dziecko do Ojca (por. Rz 8,15: Abba), biorąc Maryję do swojego życia, stając się jednocześnie i Jej dzieckiem (por. J 19,27). Osoba Jezusa Chrystusa jest „bramą” do nowego świata (por. J 10,7).

\section{Serce Jezusa - Miłość wiodąca do spełnienia osobowego}

Biblia mówi, że człowiek winien być odpowiedzialny za wnętrze swojego serca: całym sercem winien kochać Boga (por. Pwt 6,5; Mt 22,37; Mk 12,30.33; Łk 10,27), dążyć do Niego (por. Pwt 4,29), służyć Mu (por. Pwt 11,13), żyć Jego Prawem (por. 2 Mch 2,3), strzec nakazów (por. Prz 3,1), być przed Nim szczerym (por. $1 \mathrm{Krl} 8,61$ ). W sercu nie może być nienawiści do brata (por. Kpł 19,17) czy bliźniego (por. Za 7,10; 8,17), obłudy (por. Ps 12,3) i przewrotności (por. Ps 101,4). Jest ono natomiast miejscem bojaźni przed Bogiem (por. Pwt 5,29) i obecności Jego słowa (por. Pwt 6,6). Człowiek winien służyć Bogu sercem doskonałym (por. 1 Krn 28,9.19), nieskalanym i czystym (por. Ps 24,4). Jest ono miejscem chwalenia Boga (por. Ps 9,2).

Tymczasem serce człowieka jest zranione (por. Ps 109,22), mogą je zwieść źli ludzie (por. $1 \mathrm{Krl} 11,4$ ) lub złoto (por. Syr 8,2), a zły duch pragnie wyrwać z niego słowo Boże (por. Mt 13,19; Łk 8,12). W tej sytuacji samo serce człowieka wzywa go, by szukał Boga (por. Ps 27,8). Bóg bowiem stwarza i kształtuje serca ludzi (por. Ps 33,15), napomina, by oczyścić je z wszelkiego grzechu (por. Syr 38,10), otwiera (por. 2 Mch 1,4;

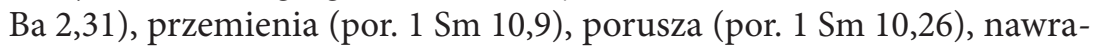
ca (por. $1 \mathrm{Krl} \mathrm{18,37),} \mathrm{kształtuje} \mathrm{jako} \mathrm{mądre} \mathrm{i} \mathrm{rozsądne} \mathrm{(por.} 1 \mathrm{Krl}$ 2,4), roztropne (por. Prz 2,2), stwarza na nowo jako czyste (por. Ps 51,12), wpisuje w nie swoje Prawo (por. Jr 31,33), umacnia (por. Ps 11,2). Pragnie mówić słowa miłości do serca swojej niewiernej „oblubienicy” (por. $\mathrm{Oz} 2$,16). Jako najlepszy lekarz przybliża się do ludzi i opatruje rany serc złamanych (por. Iz 61,1), leczy z niewierności i pragnie umiłować ich z serca (por. Oz 14,5).

Krew i woda, płynące z Serca Chrystusa, wlewają się do ludzkich serc jako najdoskonalsze lekarstwo. Głębia Osoby Syna wypełnia sobą wszelkie 
bruzdy i zakamarki ludzkiego wnętrza. Uosobiona Miłość przenika osobę przez Nią umiłowaną. Życie Jezusa Chrystusa łączy się z życiem ludzi. Cierpienie i śmierć Zbawiciela wnikają w dramat śmierci fizycznej i duchowej (grzechowej) człowieka. Chwała Zmartwychwstałego oraz łaska miłosierdzia tworzą nowe wnętrze człowieka. Według słów Chrystusa, który powiedział: „Przyjdźcie do Mnie wszyscy, którzy utrudzeni i obciążeni jesteście, a Ja was pokrzepię. Weźcie na siebie moje jarzmo i uczcie się ode Mnie, bo jestem cichy i pokornego serca, a znajdziecie ukojenie dla dusz waszych" (Mt 11,28-29). Z pokornym zaś sercem związana jest świętość (por. Dn 3,87). Jezus Chrystus wlewa w człowieka świętość Boga ${ }^{11}$.

Bóg czyni serce szerokim (por. Ps 119,32; 2 Kor 6,11). Realizuje się to w misteryjny sposób przez Słowo Wcielone i prowadzi ku niewypowiedzianej pełni życia osobowego: „Niech Chrystus zamieszka przez wiarę w waszych sercach; abyście w miłości zakorzenieni i ugruntowani, wraz ze wszystkimi świętymi zdołali ogarnąć duchem, czym jest Szerokość, Długość, Wysokość i Głębokość, i poznać miłość Chrystusa, przewyższającą wszelką wiedzę, abyście zostali napełnieni całą Pełnią Boga" (Ef 3,17-19). Wnikanie w gębię Serca Syna Bożego sprawia, że serca ludzkie stają się do Niego podobne. Duch Święty kształtuje wnętrze słabych stworzeń i wprowadza je w harmonię z Sercem Przenajświętszym.

Rozmowa z Jezusem Chrystusem rozpala serca uczniów (por. Łk 24,32). On bowiem usuwa $\mathrm{z}$ ich serc wątpliwości (por. Łk 24,38) i lęk (por. J 14,1.27). Rozpoczyna się droga do zbawienia, której pierwszym etapem jest wyznanie ustami, że Jezus jest Panem i uwierzenie $\mathrm{z}$ całego serca, że Bóg Go wskrzesił z martwych (por. Rz 10,9; Dz 8,37). Przez tę wiarę Bóg oczyszcza serca ludzi (por. Dz 15,9) oraz usprawiedliwia (por. Rz 10,10), i stają się one mieszkaniem Chrystusa (por. Ef 3,17). Mają być one utwierdzone - jako nienaganne - w świętości (por. 1 Tes 3,13).

Człowiek o sercu obłudnym winien przyjąć jako lekarstwo postawę pokuty (por. Oz 10,2) i skłonić swoje wnętrze ku napomnieniom Boga (por. Ps 119,36). Dla nawrócenia serca ważna jest też postawa bojaźni

11 Por. 1 P 3,15: „Pana zaś Chrystusa uznajcie w sercach waszych za Świętego”. Por. także Iz 8,13: „Pan Zastępów - Jego za Świętego miejcie”. 
Bożej (por. Syr 21,6). Chrystus - przebaczając - ucisza to oskarżające siebie serce (por. 1 J 3,20), a ci wszyscy, którzy mają serca czyste, stają się ludźmi szczęśliwymi (błogosławionymi; por. Mt 5,8). Bóg pragnie, by ludzie mieli właśnie takie serca i byli świadkami dla innych ${ }^{12}$.

Kontemplacja misterium Miłości uosobionej jest wnikaniem w życie wieczne Syna Człowieczego. Życie wieczne - jak wyjaśnił Jezus - polega bowiem na poznaniu Ojca, jedynego prawdziwego Boga, oraz Tego, którego On posłał, Jezusa Chrystusa (por. J 17,3). Poznanie to zaś jest już tu na ziemi tajemniczym uczestnictwem w życiu Bożym Trójcy Świętej, z niepojętą radością miłowania i istnienia w Miłości, o której mówił Chrystus: „Ja przyszedłem po to, aby [owce] miały życie, i miały je w obfitości” (J 10,10).

Wnikanie w naznaczone pełnią miłości doczesne życie Jezusa pozwala dostrzec wartość każdej ludzkiej i szlachetnej miłości - wyrażającej się na wiele sposobów. Dlatego rzetelna myśl teologiczna nie ogranicza chrześcijańskiej caritas jedynie do emocji, bądź też do (skądinąd ważnej i niezbędnej) posługi charytatywnej. Nie rozdziela też miłości Boga i miłości człowieka. Miłość do Boga zawarta jest w każdej miłości prawdziwej, zwłaszcza wymagającej poświęcenia i ofiary. Jest ona całoosobowym zwróceniem się istoty wolnej i twórczej ku innej osobie, oddaniem siebie $w$ darze, spełnieniem siebie w innych i innych w sobie. Ma ona wiele kształtów, jest m.in.: zmysłowa, rodzinna, społeczna (do środowiska życia, grupy przyjaciół), patriotyczna, ideowa (oddanie się ideom, kulturze, sztuce, tradycji), kosmiczna (do natury, przyrody) ${ }^{13}$. Wypływa z głębi osoby ludzkiej (jej serca) i obejmuje cały świat osoby (umysł - poznanie, rozum, doznawanie i tworzenie duchowe; wolę dążenia, decyzje, wybory, samookreślanie się, moralność; postępowanie i działanie; sprawczość i dokonawczość) ${ }^{14}$. Jezus Chrystus uszlachetnił

${ }^{12}$ Bóg patrzy na serce człowieka (por. $1 \mathrm{Sm} \mathrm{16,7)} \mathrm{i} \mathrm{szuka} \mathrm{człowieka} \mathrm{według} \mathrm{swe-}$ go serca (por. 1 Sm 13,14). Posyła pasterzy według swego serca (por. Jr 3,15). Jako wzór jawi się tu Maryja, która będąc posłuszną Bożemu słowu, ,zachowywała wszystkie (...) sprawy i rozważała je w swoim sercu” (Łk 2,19), „, chowała wiernie wszystkie (...) sprawy w swym sercu" (Łk 2,51).

${ }_{13}$ Por. C. S. Bartnik, Dogmatyka katolicka, t. 2, Lublin 2003'1 s. 579, 583.

${ }_{14}$ Tenże, Personalizm, Lublin 2000, s. 39. 
ludzką miłość miłością Bożą, ucząc miłości również względem: niesprawiedliwych, nieprzyjaciół i prześladujących (Mt 5,44-48; por. Łk 6,27-36; 23,34; Dz 7,60; Rz 12,20). Aby żyć w ten sposób, musi się w nas dokonać według metaforycznych słów o. Daniela Ange’a - „transplantacja Serca Jezusa". Droga ku temu jest drogą paschalną, związaną z niesieniem na co dzień własnego krzyża (por. Łk 9,23). Znamienne jest, że więcej kocha ten, komu więcej odpuszczono (por. Łk 7,47), a także często ten, kto ma trudniejsze życie.

\section{Serce Jezusa - Miłość dająca życie osobie społecznej}

Miłość wiąże się z zauroczeniem i intymną bliskością. W Biblii czytamy, że serce może być oczarowane pięknem drugiego (por. Pnp 4,9), opieczętowane drugim (Pnp 8,6: „Połóż mnie jak pieczęć na twoim sercu”). Bolesne jest, że pieczęć miłości, którą Chrystus otrzymał na swoje Serce od ludzi, to rana przebicia włócznią, jak również wszelkie, sięgające po czasy współczesne, odrzucenie, wzgarda, bluźnierstwo, lekceważenie, ignorowanie, szydzenie, świętokradztwo. Dlatego też kult Serca Jezusa zaprasza do postawy wynagrodzenia. I ze sprawiedliwości, i jako odruch ludzkiej wrażliwości, i jako modlitwa wstawiennicza za świat - dla zwyciężania zła dobrem.

Otwarte Serce Jezusa przebacza (por. Łk 23,34) i przyciąga do siebie wszystkich (por. J 12,32) - każdego osobiście i jako wspólnotę. Autorzy biblijni nadają wspólnocie społeczności Ludu Bożego charakter jednego organizmu. Bóg wielokrotnie przemawiał do: serca Jeruzalem (por. Iz 40,2; Jezus nad nią płacze: Łk 19,41-44), serca Judy (por. Jr 3,10), całego domu Izraela (por. Ez 3,7; Iz 29,13; Mt 15,8; Mk 7,6; Dz 28,27), narodu mającego serce oporne i buntownicze (por. Jr 5,23), całego ludu (por. Mt 13,15), pogan (por. Rz 1,21; stali się oni bez serca: Rz 1,31; $2 \mathrm{Tm} 3,3$ ). Stwórca chciał dać swojemu ludowi ,jedno serce i jedną zasadę postępowania" (Jr 32,39; por. Ez 11,19; 36,26). Spełnienie tych prorockich słów można dostrzec w Sercu Zbawiciela, gdyż Ono ożywia nowy Lud Boży, Kościół. W tym kluczu można dokonać próby alegorycznej (mistycznej i chrystologicznej) interpretacji fragmentu Dziejów Apostolskich, gdzie zostało napisane: „Jeden duch i jedno serce ożywiały wszystkich, którzy 
wierzyli" $(4,32)$. Można metaforycznie ująć, że wspólnota jest ożywiana Sercem Chrystusa ${ }^{15}$.

Kościół jest społecznością, w której:

- Syn z Ojcem pociesza serca ludzi (por. 2 Tes 2,17) i prowadzi je ku miłości Bożej oraz cierpliwości Chrystusowej (por. 2 Tes 3,5);

- serca wierzących napełnione są Duchem Świętym (por. 2 Kor 1,12; Ga 4,6), rządzi w nich pokój Chrystusowy $(\mathrm{Kol} 3,15)$ i rozlana jest w nich miłość Boża (por. Rz 5,5);

- członkowie - pomimo dzielących odległości - mają pozostawać zjednoczeni sercem (por. 1 Tes 2,17);

- ma w sercach pozostać otwartość na Apostoła, który założył tę wspólnotę (por. 2 Kor 6,12);

- jednym sercem walczy się wspólnie o Ewangelię (por. Flp 1,27); pod wpływem łaski śpiewa się Bogu w swoich sercach (por. Kol 3,16);

- ludzie miłują się nawzajem czystym sercem (por. 1 P 1,22).

Gdy ludzie mają serca pyszne, Bóg wówczas ich rozprasza (por. Łk 1,51), natomiast gdy słuchają Jego głosu, zwraca serce ojca do syna (por. Syr 48,10 ; Łk 1,17) i synów ku ojcom (por. Ml 3,24). Serce Jezusa daje siłę, by człowiek przebaczył z serca swemu winowajcy (por. Mt 18,35), całą swoją osobową głębią. Tylko Bóg może położyć trwały fundament dla budowania jakiejkolwiek trwałej społeczności ludzkiej, osoby społecznej: małżeństwa, rodziny, narodu, społeczności międzynarodowej, wspólnoty religijnej, zakonu, parafii, Kościoła. Jest to tajemnica społecznego wcielenia Jezusa Chrystusa, uchrystusowienia świata ${ }^{16}$.

Odejście sercem od Boga skutkuje zahamowaniem w rozwoju osobowym indywidualnym i społecznym. Często prowadzi do całkowitego rozpadu więzi międzyludzkich bądź tworzenia antywspólnot, sekt, klik, zwyrodniałych grup przestępczych. Tworzy się antycywilizacja, anty-Kościół, antyświat. Szatan sprzeciwia się stale królestwu Bożemu.

15 Oczywiście sens literalny nie zawiera bezpośredniego odniesienia do Chrystusa, niemniej Nowy Testament wielokrotnie wspomina, że wspólnota rodzącego się Kościoła ożywiana jest Bogiem (por. Rz 5,5; Ga 4,6; 2 Kor 1,12).

16 Zob. szerzej: Tenże, Chrystus - Syn Boga Żywego, dz. cyt., s. 241-248. 
Wydawać się może niektórym ludziom, że kult Serca Jezusa ma charakter tylko czysto pobożnościowy, dewocyjny, emocjonalny, niedzisiejszy, mało praktyczny, nietwórczy, pasywny i zbyt dolorystyczny. Jest to błędem, gdyż teologiczne rozumienie „serca” jako istoty, głębi bytu osoby, ontycznego ,ja”, misterium „kim ktoś jest” i zarazem „jaki jest”, sprawia, że człowiek może intuicyjnie wniknąć w misterium Miłości sprawiedliwej i miłosiernej, która ukazała piękno, sens i treść życia osobowego. Może wynagradzać za grzechy i zaniedbania popełnione ${ }^{17}$. Kontemplacja Osoby Syna Człowieczego prowadzi do stałego odkrywania prawdy o Bogu, człowieku, sensie życia, pracowitości, zdobywaniu mądrości, świecie uczuć, hartowaniu woli, kształtowaniu charakteru, pracy nad sobą, wszelkim tworzeniu, budowaniu bardziej ludzkiej cywilizacji, cierpieniu, umieraniu, śmierci, różnorakich relacjach międzyludzkich, społeczności osób w życiu ziemskim i w tajemnicy obcowania świętych. Głębia Osoby Jezusa, Jego Serce, jest „odwiecznym upragnieniem świata”, „zbawieniem” i „rozkoszą wszystkich świętych” (por. Litania do Najświętszego Serca Pana Jezusa). Misterium to wprowadza człowieka w komunię z Osobami Trójcy Świętej, z osobami stworzonymi (należącymi do Boga), z sobą samym oraz z całym światem i stawia przed kolejną tajemnicą - przyszłego życia: „(...) serce człowieka nie zdołało pojać, jak wielkie rzeczy przygotował Bóg tym, którzy Go miłuja" (1 Kor 2,9).

Serce Jezusa jest Osobą miłości i Miłością osoby ${ }^{18}$; jest objawieniem wielkości Osoby Niestworzonej, ale jednocześnie wielkości osoby stworzonej, każdego człowieka, który został przeznaczony, by stał się na wzór Osoby Niestworzonej (na wzór Syna Bożego; por. Rz 8,29) i przemienił się całkowicie w miłość.

${ }^{17}$ Por. J. KRólikowski, Intronizacja Najświętszego Serca Jezusa. Historia i założenia teologiczne, Łódź-Częstochowa 2006, s. 41. Por. także: J. Misıurek, Kult Serca Jezusowego i jego wartości duchowe w świetle wypowiedzi polskich teologów XVIII i XIX wieku, w: tenże, Historia i teologia polskiej duchowości katolickiej, t. 2: (w. XVIII-XIX), Lublin 1998, s. 39.

18 Por. C. S. BARTnik, Serce Jezusa, dz. cyt., s. 179. 


\section{Bibliografia}

Bartnik C. S., Chrystus - Syn Boga Żywego, Lublin 2000.

Bartnik C. S., Dogmatyka katolicka, t. 1-2, Lublin 1999¹-2003¹.

Bartnik C. S., Matka Boża, Lublin 2012.

Bartnik C. S., Personalizm, Lublin 2000.

Bartnik C. S., Serce Jezusa, w: C. S. Bartnik, Światło świata. Homilie, kazania, przemówienia, Lublin 1991, s. 179-181.

Gąsior A., Królikowski J., Łabuda P. (red.), Tajemnica Najświętszego Serca Jezusa. Sympozjum z okazji 50-lecia ogłoszenia przez Piusa XII encykliki Haurietis aquas, Wadowice, 17-19 listopada 2006 r., Tarnów 2007.

Katechizm Kościoła katolickiego, Poznań 1994.

Kiejza A., Serce, w: E. Gigilewicz (red.), Encyklopedia katolicka, t. 18, Lublin 2013, k. 6-7.

Królikowski, J., Intronizacja Najświętszego Serca Jezusa. Historia i założenia teologiczne, Łódź-Częstochowa 2006.

Łabuda P., Eucharystia darem miłości Serca Chrystusowego. „Bierzcie i jedzcie, to jest Ciało moje" (Mt 26,26 par.), w: A. Gąsior, J. Królikowski, P. Łabuda (red.), Tajemnica Najświętszego Serca Jezusa. Sympozjum z okazji 50-lecia ogłoszenia przez Piusa XII encykliki Haurietis aquas, Wadowice, 17-19 listopada 2006 r., Tarnów 2007, s. 66-84.

Misiurek J., Kult Serca Jezusowego i jego wartości duchowe w świetle wypowiedzi polskich teologów XVIII i XIX wieku, w: J. Misiurek, Historia i teologia polskiej duchowości katolickiej, t. 2: (w. XVIII-XIX), Lublin 1998, s. 20-77.

Misiurek J., Źródło życia i świętości. Polska teologia kultu Najświętszego Serca Jezusa, Lublin 2014.

Ks. dr hab. Jan Krzysztof Miczyński - kapłan archidiecezji lubelskiej, wyświęcony w 1996 roku. Odbył studia teologiczne magisterskie (1990-1996) i licencjackie w zakresie teologii duchowości (1998-2000) w Katolickim Uniwersytecie Lubelskim Jana Pawła II; pracę magisterską napisał pod kierunkiem ks. prof. Czesława S. Bartnika. Kontynuował studia z zakresu teologii ducho- 
wości na Papieskim Uniwersytecie Gregoriańskim w Rzymie (2000-2005). Tam obronił doktorat, przedstawiając rozprawę La cristologia esistenziale nell'esperienza e nella dottrina di Elisabetta della Trinità, której promotorem był o. prof. Bruno Secondin OCarm (†2019). Od października 2005 roku pracuje na Wydziale Teologii KUL. Od października 2017 roku pełni funkcję kierownika Sekcji Teologii Duchowości. 